\title{
ROLE OF DIFFUSION WEIGHTED MAGNETIC RESONANCE IMAGING IN ACUTE SCROTAL PAIN
}

\author{
Akut Skrotal Ağrıda Difüzyon Ağırlıklı Manyetik Rezonans Görüntülemenin Rolü
}

\author{
Mehmet BEYAZAL ${ }^{1}$, Hasan Riza AYDIN ${ }^{2}$, Maksude Esra KADIOĞLU ${ }^{1}$, \\ Fatma BEYAZAL ÇELIKER ${ }^{1}$, Mehmet Fatih İNECIKLI ${ }^{1}{ }^{1}$, Tuğba ELDEŞ ${ }^{1}$, Hüseyin EREN $^{3}$
}

\author{
${ }^{I}$ Recep Tayyip Erdogan University, School of Medicine, Department of Radiology, RIZE, TURKEY \\ ${ }^{2}$ Sağllk Bilimleri University Trabzon Kanuni SUAM, Urology Clinic, TRABZON, TURKEY \\ ${ }^{3}$ Recep Tayyip Erdogan University, School of Medicine, Department of Urology, RIZE, TURKEY
}

\begin{abstract}
Objective: The aim of this study was to investigate the contribution of quantitative apparent diffusion coefficient (ADC) measurements in the diagnosis of testis torsion.

Material and Methods: The study included 28 patients that underwent a magnetic resonance imaging (MRI) scan between January 2013 and June 2017 due to acute scrotal pain. Definitive diagnosis was based on the symptom assessment, treatment, and follow-up of the patients. Based on these parameters, patients were categorized into groups and quantitative ADC values were compared among these groups.

Results: Of the patients included in the study, 9 were diagnosed with epididymitis, 9 with orchitis, and 10 with testis torsion. The mean ADC values in the affected testes of testis torsion, epididymitis, and orchitis groups were $0.763 \pm 0.154$ $\mathrm{X} 10^{-3} \mathrm{~mm}^{2} / \mathrm{s}, 1.050 \pm 0.850 \times 10^{-3} \mathrm{~mm}^{2} / \mathrm{s}$, and $1.105 \pm 0.218$ $\mathrm{X} 10^{-3} \mathrm{~mm}^{2} / \mathrm{s}$, respectively. The mean ADC values of the affected testes were significantly lower in the testis torsion group compared to the other groups $(\mathrm{p}<0.01)$. In the testis torsion group, the mean $\mathrm{ADC}$ value of the affected testes was significantly lower compared to the unaffected testes $(0.763 \pm$ $0.154 \times 10^{-3} \mathrm{~mm}^{2} / \mathrm{s}$ vs $1.053 \pm 0.147 \times 10^{-3} \mathrm{~mm}^{2} / \mathrm{s}, \mathrm{p}<0.05$, respectively).
\end{abstract}

Conclusion: Doppler ultrasound has been used as the first choice in diagnosis of acute scrotal pain due to its being a rapid and convenient imaging modality. Quantitative ADC measurements, can be used as a helpful additional tool for the diagnosis and differential diagnosis of testis torsion from other acute scrotal pain conditions such as epididymitis or orchitis.

Keywords: Testis torsion, diffusion weighted imaging, apparent diffusion coefficient

\section{ÖZ}

Amaç: $\mathrm{Bu}$ çalışmanın amacı, testis torsiyonunun tanısında kantitatif görünür difüzyon katsayısı (GDK) ölçümlerinin katkısını araştırmaktır.

Gereç ve Yöntemler: Ocak 2013 ile Haziran 2017 tarihleri arasında akut skrotum kliniği nedeniyle ile manyetik rezonans görüntüleme yapılan 28 hasta (ortalama yaş: $37.7 \pm 21.4$ ) çalışmaya dahil edildi. Hastaların tanı, tedavi ve takiplerine dayanarak nihai tanısı belirlendi ve gruplara ayrıldı. Bu grupların difüzyon ağırlıklı görüntüleri ve GDK değerleri karşılaştırıldı.

Bulgular: Çalışmaya dahil edilen hastaların 9'u epidimit, 9'u orşit, 10'u testis torsiyonu idi. Testis torsiyonu olan 10 hastanın 5'ine orşiektomi, 5'ine orşiopeksi uygulandi. Geri kalan 18 hastanın 9'u epididimit, 9'ü orşit tanısı ile medikal olarak tedavi edildi. Testis torsiyonu, epididimit ve orşit gruplarının etkilenmiş testislerinin ortalama GDK değerleri sırası ile $0.763 \pm 0.154 \times 10^{-3}$ $\mathrm{mm}^{2} / \mathrm{s}, 1.050 \pm 0.850 \times 10^{-3} \mathrm{~mm}^{2} / \mathrm{s}$ ve $1.105 \pm 0.218 \times 10^{-3} \mathrm{~mm}^{2} / \mathrm{s}$ ölçüldü. Etkilenmiş testislerde testis torsiyonu grubunun ortalama GDK değerleri diğer gruplardan anlamlı olarak daha düşük bulundu $(\mathrm{p}<0.01)$. Ancak epididimit ve orşit arasında anlamlı farklılık saptanmadı $(\mathrm{p}>0.05)$. Ayrıca testis torsiyonu grubunda etkilenmiş ve etkilenmemiş testislerin ortalama GDK değerleri sırası ile $0.763 \pm 0.154 \times 10^{-3} \mathrm{~mm}^{2} / \mathrm{s}, 1.053 \pm 0.147 \times 10^{-3} \mathrm{~mm}^{2} / \mathrm{s}$ ölçüldü ve etkilenmiş tarafta ortalama GDK değerleri etkilenmemiş taraftaki testislerden anlamlı olarak düşük bulundu ( $\mathrm{p}<0.05)$.

Sonuç: Doppler ultrason hızlı olması ve kolay uygulanabilirliği nedeni ile akut skrotal ağrının tanısında ilk tercih olarak kullanılmaktadır. Ancak kantitatif GDK ölçümleri testis torsiyonu tanısında ve epididimit ile orşit gibi diğer akut skrotal ağrıların ayırıcı tanısında yardımcı ek bir araç olarak kullanılabilir.

Anahtar Kelimeler: Testis torsiyonu, difüzyon ağırlıklı görüntüleme, görünür difüzyon katsayısı 


\section{INTRODUCTION}

Testis torsion is one of the important causes of acute scrotal pain, which requires urgent surgical treatment. Any delay in the diagnosis or treatment can result in irreversible damage. Ultrasonography, which has high sensitivity and specificity, has been used as the main imaging modality in diagnosis of testis torsion and its differential diagnosis from other acute scrotal pathologies. However, it may not always be sufficient for definitive diagnosis (1-5). Diffusion-weighted imaging (DWI) is a scanning method that reverberates the movements of water protons. An important advantage of this technique is that there is no requirement for contrast usage. Various pathologies such as tumor infiltration, inflammation, and ischemia, can affect the diffusion characteristics of the tissue via changing the histological architecture of the tissue, which results in signal differences on DWI (6). There are many experimental studies on rats that have evaluated testis torsion with DWI and important findings were reported in those studies (7). However, clinical studies on this issue are very limited. The aim of this study was to evaluate the value of DWI and quantitative apparent diffusion coefficient (ADC) measurements for the diagnosis of testis torsion and differential diagnosis from other conditions.

\section{MATERIALS AND METHODS}

The local ethics committee of our institution (Recep Tayyip Erdoğan University, Non-Invasive Clinical Research Ethics Committee, 17.03.2017, 2017/48) approved the present retrospective research protocol. A total of 32 patients who had undergone magnetic resonance imaging (MRI) for acute scrotal pain between January 2013 and June 2017 were examined. Two patients with poor MRI image quality due to motion artifacts, a patient with testicular abscess, and a patient whose diagnosis, treatment, and follow-up information could not be retrieved were excluded from this study. Therefore, 28 subjects (age, $37.7 \pm 21.4$ years; range 7-77 years) were included in the analysis. Final diagnosis was based on physical examination, laboratory tests (blood cell count, C- reactive protein and urine sample) results, treatment, and follow-up information. Based on these data, the patients were categorized into three groups as epididymitis, orchitis and testis torsion. The MRI images of each patient were evaluated and the findings were compared.

\section{Imaging}

The MR scans with a $1.5 \mathrm{~T}$ scanner (Siemens Magnetom Aera, Erlangen, Germany) were performed and the axial plane T2-weighted sequence were obtained for all patients. The DWI (TR/TE, 13300/62 s; matrix, 128 x 128; FOV, 350 mm; slice number, 25; slice thickness, $5 \mathrm{~mm}$; PAT factor, 2) were obtained. The echo-planar DWI was performed with $0 \mathrm{~s} / \mathrm{mm} 2$, $1000 \mathrm{~s} / \mathrm{mm} 2$ and an ADC map.

Image analysis

Post-processing software (Syngo. via VA20 software, Siemens Healthcare, Forchheim, Germany) was used for the analysis of image. In axial T2 weighted images, the sizes of the testis and epididymis at the affected side, and the orientation of testis as vertical, transverse, or oblique were evaluated. The presence of 'twisted spermatic cord' sign was assessed in sequential sections. On the ADC maps, the circular regions-ofinterest (ROI) were used to calculate testes ADC values. The images were assessed by three radiologists and discussed.

\section{Statistical analysis}

The Statistical Package for the Social Sciences (SPSS), version 13.0, for Windows (SPSS, Chicago, IL, USA) were used for the statistical analyses. Continuous variables are demonstrated as the mean \pm standard deviation (SD). The normality of the distribution for all variables was identified by the Kolmogorov-Smirnov test. The repeated one way analysis of variance test was used to compare the groups. The Student's $t$-test or 
Mann-Whitney $\mathrm{U}$ test were performed according to the distribution of variables for the subgroup analysis of testis torsion. A value of $p<0.05$ was regarded as statistically significant level.

\section{RESULTS}

Of the subjects, 9 were diagnosed with epididymitis, 9 with orchitis, and 10 with testis torsion. The mean age of these patient subsets was $41.3 \pm 23.1$ years, $50.1 \pm$ 15.1 years, and $23.3 \pm 17.4$ years, respectively. Of the 10 patients with testis torsion, 5 underwent orchiectomy because the intraoperative findings showed hemorrhagic necrosis of the affected testis. Histopathological examination in these cases confirmed the presence of hemorrhagic necrosis. In the other 5 patients diagnosed with testis torsion, perfusion improved following surgical detorsion of the affected testis, and these patients were treated with orchiopexy. The remaining 18 patients ( 9 with epididymitis and 9 with orchitis) were treated using pharmacotherapy. In the sequential sections of $\mathrm{T} 2$ weighted images, 'twisted spermatic cord' sign was observed in the affected testes of 8 out of $10(80 \%)$ patients with testis torsion while this sign was not detected in $2(20 \%)$ patients (Figure $1)$.

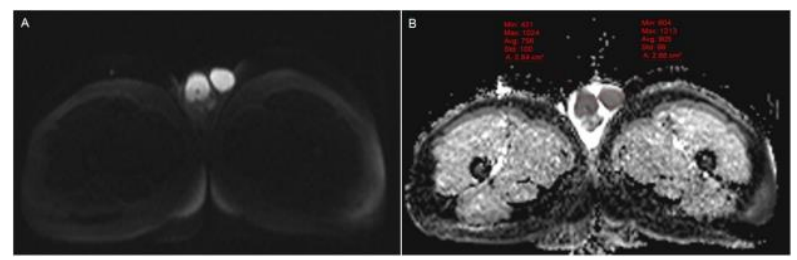

Figure 1. Axial T2-weighted images demonstrating left twisted spermatic cord.

'Twisted spermatic cord' sign was not observed in any of the patients with testis torsion at the unaffected side, or in any side of the patients with epididymoorchitis or epididymitis. Six of the patients with testis torsion $(60 \%)$ had their affected testes oriented in the transverse position and positioned high. The mean
ADC values of the affected testes in the testis torsion, epididymitis, and orchitis groups were $0.763 \pm$ $0.154 \times 10^{-3} \mathrm{~mm}^{2} / \mathrm{s}, 1.050 \pm 0.850 \times 10^{-3} \mathrm{~mm}^{2} / \mathrm{s}$, and $1.105 \pm 0.218 \times 10^{-3} \mathrm{~mm}^{2} / \mathrm{s}$, respectively (Figure $2-5$ ).

For affected testes, the mean ADC value was significantly lower in the testis torsion group than those in the other groups $(p<0.01)$, whereas there was no significant difference in ADC values between the groups with epididymitis and orchitis ( $p>0.05)$. The mean ADC values of the unaffected testes in patients with testis torsion, epididymitis, and orchitis groups were $1.053 \pm 0.147 \times 10^{-3} \mathrm{~mm}^{2} / \mathrm{s}, 1.056 \pm 0.127 \times 10^{-3}$ $\mathrm{mm}^{2} / \mathrm{s}$, and $1.031 \pm 0.153 \times 10^{-3} \mathrm{~mm}^{2} / \mathrm{s}$, respectively. No significant difference were found among the groups ( $p>0.05$ ). In the patients with testis torsion, the mean ADC values of the testes that were treated by orchiopexy and orchiectomy were $0.823 \pm 0.155 \times 10^{-3}$ $\mathrm{mm}^{2} / \mathrm{s}$ and $0.707 \pm 0.135 \times 10^{-3} \mathrm{~mm}^{2} / \mathrm{s}$, respectively (Figure 2, 3).

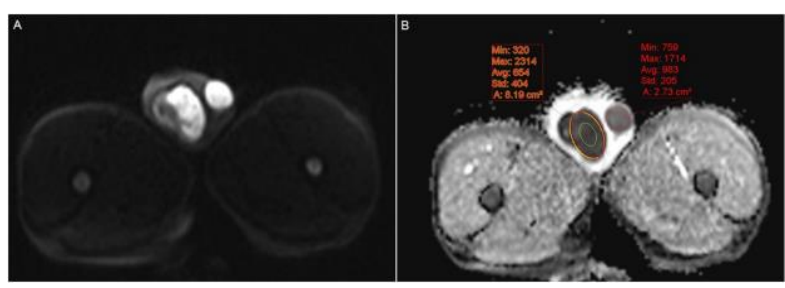

Figure 2. Acute right testis torsion in a 29-year-old patient that underwent orchiopexy. (A) Diffusionweighted imaging. (B) On the ADC map, the right testicle demonstrates lower ADC value than the left testicle.

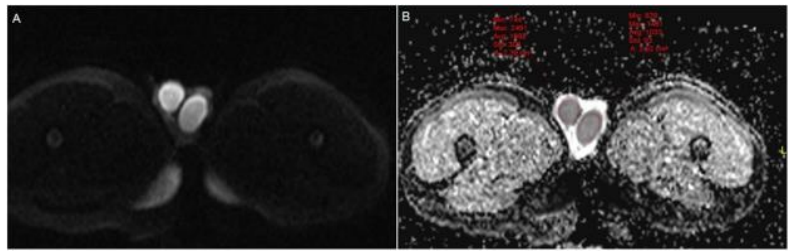

Figure 3. Acute right testis torsion resulted in hemorrhagic necrosis in a 19-year-old patient that underwent orchiectomy. (A) Diffusion-weighted imaging. (B) On the ADC map, the right testicle shows lower ADC value than the left testicle. 
Although the patients with orchiopexy had a numerically higher mean $\mathrm{ADC}$ value than the patients with orchiectomy, the difference in ADC values between groups did not reach a significant level ( $p$ $>0.05$ ). Additionally, the mean ADC values of the affected and unaffected testes in the testis torsion group were $0.763 \pm 0.154 \times 10^{-3} \mathrm{~mm}^{2} / \mathrm{s}$ and $1.053 \pm 0.147 \mathrm{X}$ $10^{-3} \mathrm{~mm}^{2} / \mathrm{s}$, respectively, with the affected testes having a significantly lower ADC value $(\mathrm{p}<0.05)$.

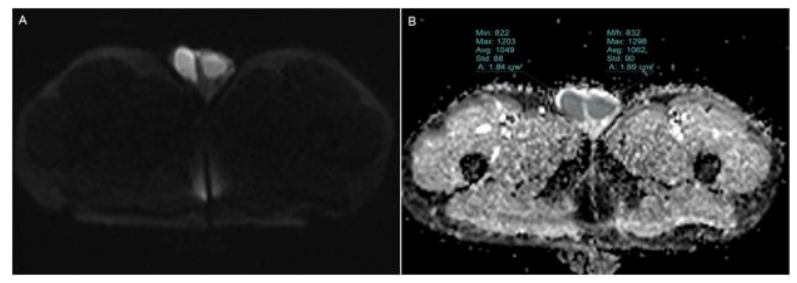

Figure 4. Acute left epididymitis in a 21-year-old patient. On DWI (A) and ADC map (B) both testis signals are observed as nearly equal.

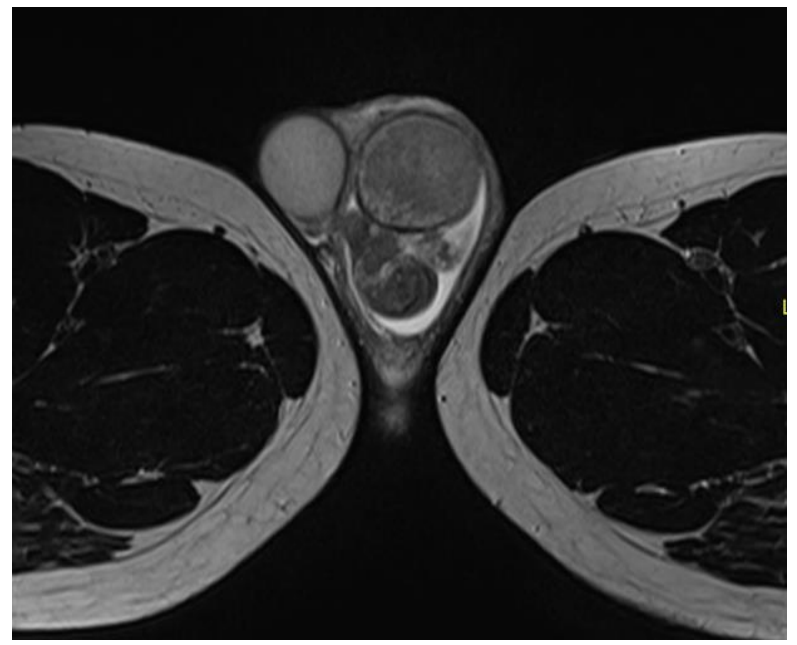

Figure 5. Acute left epididymo-orchitis in a 52-yearold patient. On DWI (A) and ADC map (B) both testes are observed as isointense.

\section{DISCUSSION}

Testis torsion is an urological emergency that causes ischemia in the testicles due to twisting of the spermatic cord. The parenchymal damage of the testes may occur at various grades depending on the delay of diagnosis and the severity of the testis torsion. In the case of partial torsion, initially, venous congestion and interstitial edema develops. If the testis blood flow is completely obstructed, the ischemic damage progresses which leads to tissue necrosis and interstitial hemorrhage $(7,8)$. Color Doppler ultrasound (CDUS) is known as the method that provides the best result in the diagnosis of scrotal disorders. It is an easily accessible and inexpensive diagnostic tool that can be used as the first-line method for diagnosis in patients with scrotal pain. It has been demonstrated that the specificity and sensitivity of CDUS in the diagnosis of testis torsion was over the value of $90 \%(4,9)$. However, when evaluating testis blood flow, CDUS can't reveal out the tissue and cellular changes caused by the compromised perfusion. Moreover, it is operator dependent and might yield inconclusive results.

DWI is an imaging technique that reflects in vivo movement of water protons. Factors, including tissue organization, distance between extracellular structure and intensity of cells in tissue effect the motion of water. Initially, DWI has been used to visualize cerebral infarctions. The obvious diminish in diffusion in condition with cerebral infarction has resulted from the changes of fluid balance in intracellular and extracellular compartments (10-12). Pathological changes that ocur at tissue and cellular levels result in signal alterations on DWI. There are animal studies evaluating testis torsion with DWI. Kangasniemi et al. have shown that ADC values were reduced in ischemic testis compared to the control testis after funicle ligation of rat testicles. Histological studies demonstrated mild blood congestion and interstitial edema in the capillaries 1 hour after ligation but cellular morphology did not change (8). In an experimental rat study by Kaipia et al., it has been demonstrated that decreased blood flow during torsion was followed by reduced ADC values in both 360 degrees (12.4\% decrease) and 720 degrees (10.8\% decrease) of torsion, indicating measurable ischemiainduced tissue changes after $1 \mathrm{~h}$ of torsion (13). In 
another study, Ufuk et al. created 360 degrees of torsion in the testes of rats, and when compared to 8th hour DWI images, they found that ADC values calculated from the 24th hour DWI images showed significant decrease. However, histopathological examination showed that $87.5 \%$ of the testes in this group were still recoverable (7). These findings suggest that ADC values calculated from DWI images can also reflect the early stages of ischemic damage. In our study, the mean ADC value of the recoverable testes that were treated with oechiopexy was $0.823 \pm 0.155 \mathrm{X}$ 10-3 $\mathrm{mm} 2 / \mathrm{s}$, and was significantly decreased when compared to those in unaffected side and other groups (epididymitis and orchitis).

The presence of widespread hemorrhage in the twisted testis is a sign of severe ischemic damage, and indicates the low chance of recoverability of the affected testis. In the study by Ufuk et al., it has been reported that none of the testes with widespread hemorrhage on histopathological examination were recoverable. They found that these testes had significantly decreased ADC values compared to the control group (7). In our study, 4 of the 5 orchiectomized testes had hemorrhagic necrosis. Although the mean ADC value of the orchiectomized testes was decreased when compared to those in treated with orchiopexy, the difference was not statistically significant. There are limited number of clinical studies evaluating acute scrotal pathologies with MRI and DWI. In a retrospective study by Terai et al. it has been demonstrated that the specificity and sensitivity of dynamic contrast-enhanced subtraction MRI in the diagnosis of testis torsion was $100 \%$ and $93 \%$, respectively. However, the authors stated that it was not possible to rule out intermittent torsion with MRI (14). In another study, it has been found that the sensitivities in the diagnosis of complete torsion as $100 \%$ for dynamic contrast-enhanced MRI and $75 \%$ for T2- and T2*-weighted imaging. In that same study, T2and $\mathrm{T} 2 *$-weighted imaging were found to have $100 \%$ accuracy in detecting testicular necrosis (15). Trambert et al. used MRI to discriminate between epididymitis and subacute testicular torsion in their study. They evaluated 'torsion knot and whirlpool patterns' caused by twisting of the spermatic cord and spermatic cord vascularity findings. It was stated that the differantial diagnosis of testis torsion from epididymitis could be performed with the high accuracy based on these MRI findings (16). In our study, $80 \%$ of the patients with testis torsion were detected to have 'twisted spermatic cord' sign at the affected side. Additionally, $60 \%$ of the twisted testes were oriented in transverse position and positioned high.

To our knowledge, there is only one clinical study that has evaluated testis torsion with DWI. That study found a significantly lower mean ADC value in the twisted testes compared to those in unaffected testes in patients with testis torsion. In addition, no significant difference in the mean $\mathrm{ADC}$ value of the testes was found between the affected and unaffected side in other scrotal disorders. However, they observed necrosis in the majority of testis torsion cases, and very few cases were non-necrotic. Additionally, there was no case of orchitis (5). Another study mentioned DWI imaging parameters but did not mention any DWI imaging findings (17). In our study, the number of recoverable cases that underwent orchiopexy and the number of cases that underwent orchiectomy due to necrosis were equal. We also had a group of patients with orchitis. However, the limited number of cases and the retrospective design are the limitations of this study.

In conclusion, Doppler ultrasound has been used as the first choice in diagnosis and differential diagnosis of acute scrotal pain due to its rapid and convenient imaging modality. However, in the requirement an additional imaging modality, diffusion MRI and quantitative $\mathrm{ADC}$ measurements can be an option as a useful tool in the diagnosis of testis torsion and to distinguish between other acute scrotal pain conditions such as epididymitis and orchitis. 
Conflict of Interest: The authors declare that they have no conflict of interest.

\section{REFERENCES}

1. Patriquin HB, Yazbeck S, Trinh B, Jéquier S, Burns PN, Grignon A et al. Testicular torsion in infants and children: diagnosis with doppler sonography. Radiology. 1993;188(3):781-5.

2. Luker GD, Siegel MJ. Color Doppler sonography of the scrotum in children. AJR Am J Roentgenol. 1994;163(3):649-55.

3. Pepe P, Panella P, Pennisi M, Aragona F. Does color Doppler sonography improve the clinical assessment of patients with acute scrotum? Eur $\mathbf{J}$ Radiol. 2006;60(1):120-4.

4. Yagil Y, Naroditsky I, Milhem J, Leiba R, Leiderman M, Badaan S et al. Role of Doppler ultrasonography in the triage of acute scrotum in the emergency department. J Ultrasound Med. 2010;29(1):11-21.

5. Maki D, Watanabe Y, Nagayama M, Ishimori T, Okumura A, Amoh Y et al. Diffusion-weighted magnetic resonance imaging in the detection of testicular torsion: feasibility study. J Magn Reson Imaging. 2011;34(5):1137-42.

6. Beyazal M, Avcu S, Celiker FB, Yavuz A, Toktas O. The efficiency of apparent diffusion coefficient quantification in diagnosis of acute cholecystitis and in differentiation of cholecystitis from extrinsic benign gallbladder wall thickening. Jpn J Radiol. 2014;32(9):545-51.

7. Ufuk F, Herek D, Herek O, Akbulut M. Role of diffusion weighted magnetic resonance imaging in a rat model of testicular torsion. $\mathrm{Br} \mathrm{J}$ Radiol. 2016;89(1068):20160585.

8. Kangasniemi M, Kaipia A, Joensuu R. Diffusion weighted magnetic resonance imaging of rat testes: a method for early detection of ischemia. J Urol. 2001;166(6):2542-4.
9. Atkinson GO Jr, Patrick LE, Ball TI Jr, Stephenson CA, Broecker BH, Woodard JR. The normal and abnormal scrotum in children: evaluation with color Doppler sonography. AJR Am J Roentgenol. 1992;158(3):613-7.

10. Padhani AR, Liu G, Koh DM, Chenevert TL, Thoeny HC, Takahara $\mathrm{T}$ et al. Diffusion-weighted magnetic resonance imaging as a cancer biomarker: consensus and recommendations. Neoplasia. 2009;11(2):102-25.

11. Koh DM, Collins DJ. Diffusion-weighted MRI in the body: applications and challenges in oncology. AJR Am J Roentgenol. 2007;188(6):1622-35.

12. Avcu S, Bulut MD, Yavuz A, Bora A, Beyazal M. Value of DWMRI ADC quantification of colonic wall lesions in differentiation of inflammatory bowel disease and colorectal carcinoma. Jpn J Radiol. 2014;32(1):6-13.

13. Kaipia A, Ryymin P, Mäkelä E, Aaltonen M, Kähärä V, Kangasniemi M. Magnetic resonance imaging of experimental testicular torsion. Int $\mathbf{J}$ Androl. 2005;28(6):355-9.

14. Terai A, Yoshimura K, Ichioka K, Ueda N, Utsunomiya N, Kohei $\mathrm{N}$ et al. Dynamic contrastenhanced subtraction magnetic resonance imaging in diagnostics of testicular torsion. Urology. 2006;67(6):1278-82.

15. Watanabe Y, Nagayama M, Okumura A et al. MR imaging of testicular torsion: features of testicular hemorrhagic necrosis and clinical outcomes. J Magn Reson Imaging. 2007;26(1):100-8.

16. Trambert MA, Mattrey RF, Levine D, Berthoty DP. Subacute scrotal pain: evaluation of torsion versus epididymitis with MR imaging. Radiology. 1990;175(1):53-6.

17. Mäkelä E, Lahdes-Vasama T, Ryymin P, Kähärä V, Suvanto J, Kangasniemi $M$ et al. Magnetic resonance imaging of acute scrotum. Scand J Surg. 2011;100(3):196-201. 